\title{
ENDOSKOPINIS ULTRAGARSINIS BILIARINIS DRENAŽAS. KLINIKINIS ATVEJIS
}

\author{
Eglẻ Kasparaityté ${ }^{2}$, Olegas Deduchovas' ${ }^{1}$, Vitalijus Eismontas ${ }^{1}$, \\ Narimantas Evaldas Samalavičius ${ }^{1}$ \\ ${ }^{1}$ Klaipèdos universitetinès ligoninès pilvo ir robotinès chirurgijos skyrius, \\ ${ }^{2}$ Lietuvos sveikatos mokslu universiteto Medicinos akademija, Medicinos fakultetas
}

Raktažodžiai: endoskopinis ultragarsinis biliarinis drenažas, perkutaninis transhepatinis biliarinis drenažas, endoskopinè retrogardinè cholangiopankreatografija.

\section{Santrauka \\ Pristatomas 71 metų pacientas, kuriam dèl mechaninès geltos endoskopinio ultragarso kontrolejje atliktas bilia- rinis drenažas. Anksčiau pacientui atlikta gastrektomija dèl skrandžio kūno adenokarcinomos. Operuojant skran- dis pašalintas kartu su distaline stemplès dalimi, atlikta stemplès jungtis su tuščiaja žarna. Nors biliariniam dre- nažui atlikti dažniausiai taikoma endoskopinè retrogra- dinè cholangiopankreatografija (ERCP) ar perkutaninis transhepatinis biliarinis drenažas (PTBD), kaip alterna- tyvi priemone gali būti pasirinktas endoskopinis ultra- garsinis biliarinis drenažas (EUS - BD). Renkantis, kuri metodą panaudoti, svarbu apsvarstyti tokius veiksnius, kaip techninè kompetencija, nepageidaujamų šalutinių reiškinių rizika, pooperacinès anatominès ypatybès [2].}

\section{Ivadas}

Endoskopinè retrogradinè cholangiopankreatografija (ERCP) išlieka pagrindiniu metodu atliekant biliarini drenažą, tačiau dẻl anatominių ypatybių, dvylikapirštės žarnos obstrukcijos, periampulinio divertikulo, didelių tumorų $[3,1]$ tampa negalima. Pacientams dèl atliktos Billroth II tipo operacijos, Roux-en-Y rekonstrukcijos duodenoskopu pasiekti didiji dvylikapirštės žarnos speneli yra techniškai sudètinga ar neįmanoma [1]. Perkutaninis transhepatinis biliarinis drenažas (PTBD) atliekamas esant nesèkmingai ar negalimai ERCP, tačiau siejamas su padidejjusiu sergamumu, diskomfortu, reintervencijomis [3]. Kaip alternatyvi priemonè gali būti taikomas endoskopinis ultragarsinis biliarinis drenažas (EUS - BD) [2]. EUS - BD gali būti atliekamas intrahepatiškai arba ekstrahepatiškai [1].

Aprašysime klinikini atveji, kai 71 metų mechanine gelta sergančiam pacientui, kuriam prieš dvejus metus atlikta gastrektomija dèl skrandžio kūno adenokarcinomos, atliktas endoskopinis ultragarsinis biliarinis drenažas.

\section{Klinikinis atvejis}

2021 metų rugpjūčio mènesị 71 metų vyras kreipèsi dèl geltos, skundèsi pilvo skausmais. Iš anamnezès žinoma, kad 2019 metais pacientui atlikta gastrektomija bendroje intubacinèje nejautroje dèl G3 skrandžio kūno adenokarcinomos, difuzinio tipo pagal Lauren. Operacijos metu skrandis pašalintas kartu su distaline stemplès dalimi, atlikta stemplès jungtis su tuščiaja žarna. Apžiūros metu oda ir junginès buvo pageltusios, palpuojant pilvas minkštas, skausmingas po dešiniuoju šonkaulių lanku. Atlikus radiologinius tyrimus, rasta biliarinès obstrukcijos požymių. Pilvo KT tyrimo metu rasta didoka, persilenkusi tulžies pūslè netolygiai sustorejjusiomis sienelėmis, išryškejjo kepenų vartų srities infiltracija. Atlikus šlapimo tyrimą, bilirubino rasta $17 \mu \mathrm{mol} / \mathrm{l}$, urobilinogeno 16 $\mu \mathrm{mol} / 1$. Kraujyje bendro bilirubino koncentracija siekè 247

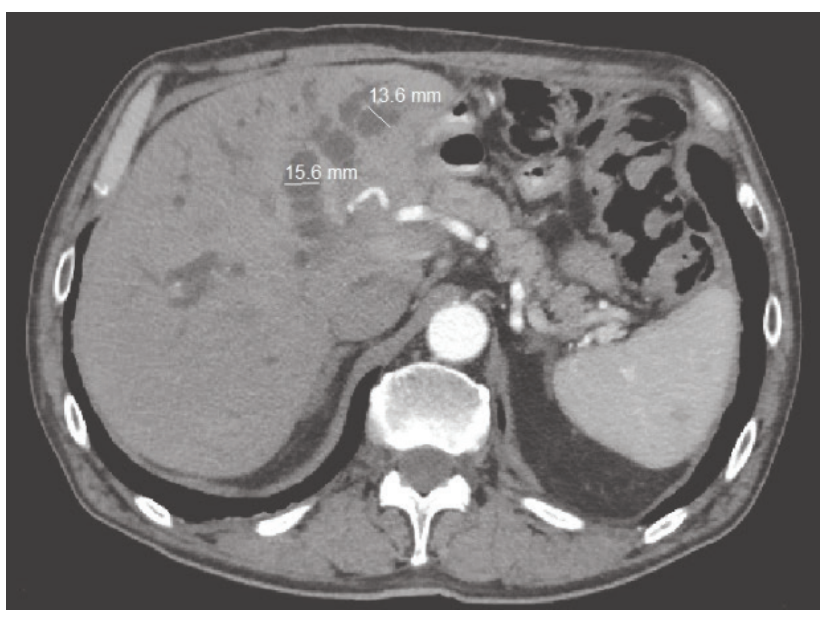

1 pav. Plèsti intrahepatiniai latakai iki $13-15 \mathrm{~mm}$ prieš stentavimą 
$\mu \mathrm{mol} / \mathrm{l}$, tiesioginio bilirubino - $190 \mu \mathrm{mol} / \mathrm{l}$, nustatyta padidèjusi kepenų fermentų koncentracija. Pacientui diagnozuota mechaninè gelta dèl ductus choledochus obstrukcijos. Pacientas stacionarizuotas ị pilvo ir robotinès chirurgijos skyrių. Skirtas konservatyvus gydymas, infuzoterapija, analgetikai, antibiotikai. Atlikta transhepatine hepatikojejunostomija metaliniu stentu (1,2 pav.). I kairi kepenų lataką iki bifurkacijos įvestas $100 \mathrm{~mm}$ ilgio $10 \mathrm{~mm}$ pločio stentas. Operacija atlikta endoskopinio ultragarso, rentgeno ir vaizdo kontroleje (3 pav.). Po dviejų parų pakartojus tyrimus, kraujyje bendro bilirubino koncentracija sumažèjo iki 145,5 $\mu \mathrm{mol} / 1$, tiesioginio bilirubino koncentracija iki 92,7 $\mu \mathrm{mol} / \mathrm{l}$, kliniškai pacientas jautėsi geriau, išleistas tolimesniam ambulatoriniam gydymui. Po vienuolikos dienų pakartojus biochemini

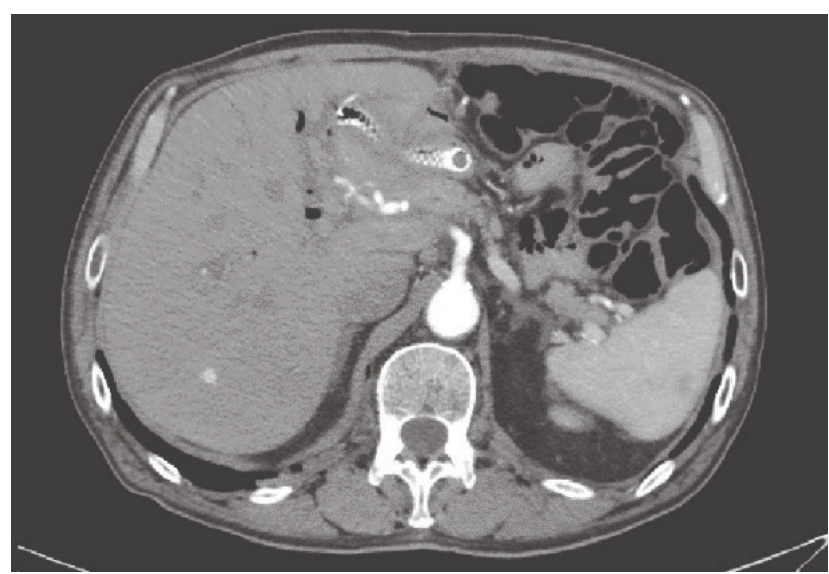

2 pav. Susiaureję̨ intrahepatiniai latakai iki $6 \mathrm{~mm}$ po stentavimo

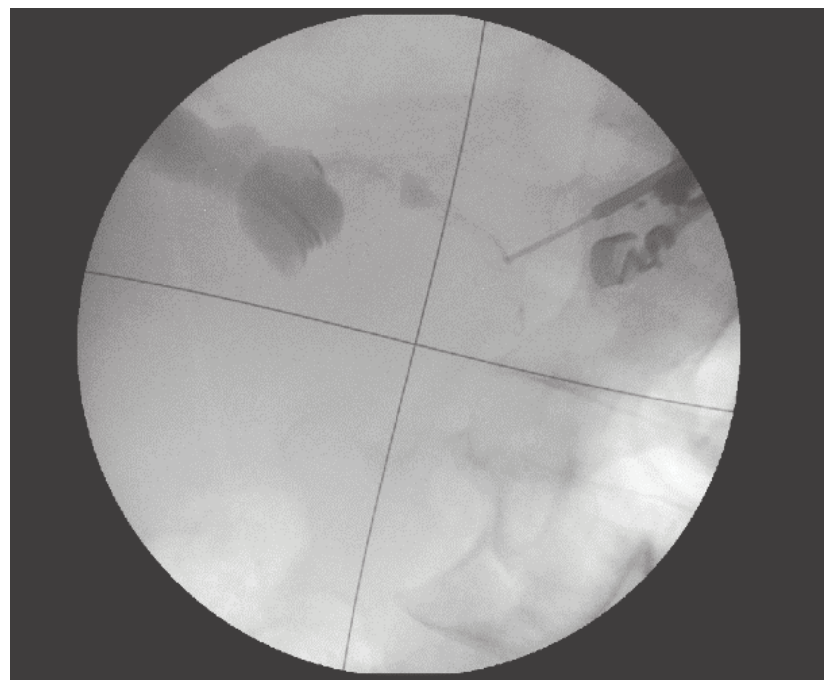

3 pav. Endoskopinio ultragarso kontroleje išpunktuotas kairys skiltinis latakas, leidžiamas kontrastas kraujo tyrimą, tiesioginio bilirubino koncentracija rasta sumažèjusi iki 45, $4 \mu \mathrm{mol} / 1$, o bendro bilirubino koncentracija sumažejusi iki $64,3 \mu \mathrm{mol} / 1$.

\section{Diskusija}

Biliarinis drenažas, atliekamas endoskopinio ultragarso kontrolëje, dažniausiai yra sėkmingas. T. Iwashita, S. Uemura ir kt. atliktame tyrime, kurio metu remtasi 2007-2019 m. klinikiniais duomenimis, siekta palyginti EUS - ABS (endoskopinis ultragarsinis antegradinis stentavimas) ir PTBD metodus pacientams su distaline piktybine biliarine obstrukcija, techninè ir klinikinè sèkmė taikant EUS - ABS siekè po $97,1 \%$, atliekant PTBD atitinkamai $96,6 \%$ ir $93,1 \%$. Tyrimo metu nustatytas neigiamų šalutinių reiškinių dažnis taikant EUS - ABS metodą siekè 11,4 \%, kai taikant PTBD siekè 27,6 \% [4]. Galima teigti, kad EUS ir PTBD yra efektyvūs ir patikimi metodai pacientams su biliarine obstrukcija gydyti. Perkutaninis transhepatinis išorinis drenavimas - dažniausiai taikomas metodas biliariniam drenažui atlikti. Lietuvoje endoskopinis ultragarsinis biliarinis drenažas - naujas metodas, publikacijų apie šios technikos taikymą Lietuvoje nėra.

\section{Išvados}

1. Endoskopinè retrogradinè cholangiopankreatografija (ERCP) - standartinis metodas biliariniam drenažui pacientams su normalia anatomija atlikti [3].

2. Perkutaninis transhepatinis biliarinis drenažas (PTBD) taikomas esant negalimai ERCP, tačiau siejamas su didesne nepageidaujamų šalutinių reiškinių rizika nei ERCP [3].

3. Endoskopinis ultragarsinis biliarinis drenažas (EUS - BD) - alternatyvi priemoné, kai drenavimas taikant ERCP dèl anatominių ypatybių yra techniškai negalimas.

4. Renkantis, kuri metodą taikyti, svarbu ịvertinti technines galimybes, nepageidaujamų reiškinių riziką, anatomines ypatybes.

\section{Literatūra}

1. Boulay BR, Lo SK. Endoscopic Ultrasound - Guided Biliary Drainage. Gastrointestinal Endoscopy Clinics of North America 2018; 28(2): 171-185.

https://doi.org/10.1016/j.giec.2017.11.005

2. Leung Ki EL, Napoleon B. Endoscopic ultrasound - guided biliary drainage: A change in paradigm? World Journal Gastrointestinal Endoscopy 2019;11(5):345-353.

https://doi.org/10.4253/wjge.v11.i5.345

3. Iwashita T, Doi S, Yasuda I. Endoscopic ultrasound-guided biliary drainage: a review. Clinical Journal of Gastroenterology 2014;7(2):94-102.

https://doi.org/10.1007/s12328-014-0467-5

4. Iwashita T, Uemura S, Mita N, Iwasa Y, Ichikawa H, Mukai T, 
Yasuda I, Shimizu M. Endoscopic ultrasound guided - antegrade biliary stenting vs percutaneous transhepatic biliary stenting for patients with surgically altered anatomy. Journal Hepatobiliary Pancreatic Sciences 2020;27(12): 968-976.

https://doi.org/10.1002/jhbp.823

\section{CASE REPORT: ENDOSCOPIC ULTRASOUND - GUIDED BILIARY DRAINAGE E. Kasparaitytė, O. Deduchovas, V. Eismontas,} N.E. Samalavičius

Keywords: endosopic ultrasound - guided biliary drainage, percutaneous transhepatic biliary drainage, endoscopic retrograde cholangiopancreatography.

Summary

We present a 71 years old male who underwent biliary drainage under endoscopic ultrasound control for mechanical jaundice.
The patient had previously undergone gastrectomy for adenocarcinoma of the gastric body. During the surgery, the stomach was removed along with the distal part of the esophagus, the esophagus was connected to jejunum. Although endoscopic retrograde cholangiopancreatography (ERCP) or percutaneous transhepatic biliary drainage (PTBD) are the most commonly used methods, endoscopic ultrasonic biliary drainage (EUS - BD) may be chosen as an alternative. When choosing which method to use, it is essential to consider such factors as technical competence, risk of adverse events, postoperative anatomical features [2].

Correspondence to: o.deduchovas@gmail.com

Gauta 2021-10-04 